\title{
ANALYSIS OF FACTORS AFFECTING THE IMPORT OF DAIRY MILK (CASE STUDY: THE IMPORT OF DAIRY MILK IN INDONESIA)
}

\author{
Kustopo Budi Raharjo, Budi Rahardjo, and Solikhin \\ Diponegoro University, Jl. Prof. Sudarto SH, Tembalang, Semarang, Indonesia \\ Correspondence Email: Kustopo.65@gmail.com
}

Submitted 27 January 2020; Accepted 21 October 2020

\begin{abstract}
ABSTRAK
Pasokan susu segar dalam negeri (SSDN) belum dapat memenuhi kebutuhan konsumsi susu dalam negeri sehingga pemenuhan kebutuhan konsumsi susu dilakukan pula dengan impor susu. Penelitian ini bertujuan untuk analisis faktor-faktor yang mempengaruhi impor susu di Indonesia. Metode penelitian menggunakan teknik analisis kuantitatif yaitu regresi linier berganda. Penelitian ini dilakukan di Indonesia dengan menggunakan data sekunder tahun 2006-2016 yang diperoleh di Badan Pusat Statistik dan Kementerian Pertanian serta literatur-literatur lain terkait penelitian. Variabel penelitian meliputi kurs, PDB perkapita, ekspor susu, dan produksi susu. Variabel yang memiliki hubungan positif signifikan terhadap impor susu Indonesia adalah PDB perkapita, ekspor susu, dan produksi susu. Sedangkan, variabel kurs memiliki hubungan negatif terhadap impor susu.
\end{abstract}

Kata kunci: determinan, impor susu, regresi linear berganda

\begin{abstract}
The supply of fresh dairy milk in the country (SSDN) has not been able to meet the needs of domestic dairy milk consumption so that the fulfillment of dairy milk consumption needs is also done by importing dairy milk. This study aims to analyze the factors that influence milk imports in Indonesia. The research method uses quantitative analysis techniques, namely multiple linear regression. This research was conducted in Indonesia using secondary data from 2006-2016 obtained at the Central Statistics Agency and the Ministry of Agriculture and other literature related to research. Research variables include exchange rates, GDP per capita, milk exports, and milk production. The results showed that variables GDP per capita, milk exports, and milk production have positive influence. Meanwhile, exchange rate has negative influence for milk imports.
\end{abstract}

Keywords: determinant, milk imports, multiple regression linear

\section{INTRODUCTION}

Import is one of the government policies and is aimed at international trade in Indonesia. The amount of domestic production that is unable to meet that of the domestic needs is the cause of the implementation of the import policy (Tri, 2011; Baohi Song et al., 2009). A negative relationship between imports and production is revealed by a study conducted by Syariah and Idqan (2007). If a country has a declining volume of imports for a commodity, it is assumed that the country has an increasing volume in production. Meanwhile, if the imports for a commodity increase, it is assumed that the production declines. Alternatively stated, the increase in the volume of imports is presumed to be caused by insufficient domestic production, making it is necessary to import. Foreign exchange rates have a negative relationship with imports (Andi dan Syamsul, 2009). Parveen (2012) showed that there is a negative and significant relationship between the US dollar exchange 
rate and the rupiah toward the import volume of Indonesia.

Imports are also highly dependent on the gross domestic product (GDP) because GDP is a source of financing for imports. A study conducted by Imamudin (2008) showed a positive relationship between GDP and imports. An increase in national income will increase imports of consumer goods in Indonesia, assuming cateris paribus. Imports are applied to some goods/services whose quantity cannot yet be met in the country, including milk products. Up to 78.89 percent of the milk supply is fulfilled by imports while only 22.11 percent of it was fulfilled by domestic milk producers, which are smallholder dairy farmers.

Milk is an animal-based food material with high nutritional content. It is a good source of high plant protein with polyvalent that has a role in immune function and the transportation and absorption of nutrients as well as important vitamins and minerals for the human body (Pereira, 2014). It makes the demand for milk increasing together with the increasing human population and other factors affecting the import of Indonesian milk. Such import is carried out so that domestic milk needs can be fulfilled. The development of milk in 1996-2016 is shown in Table 1.
The role of the agricultural sector in economic development is crucial as most members of communities in poor countries rely on this sector. Rising public welfare in the agricultural sector becomes one of the attempts to eradicate poverty in the majority of people in the agricultural sector. Agricultural sector reform serves as an attempt to overcome the problem of the widening economic crisis, which is performed by increasing food security in the short term (Erwidodo, Wittwer, \& Stringer, 2009).

As an agricultural sub-sector, livestock is essential to develop, aiming to stimulate the ability of local farmers to improve the domestic milk supply. To date, local breeders are only able to meet around 25 - 30 percent of the domestic supply (Directorate General of Animal Husbandry, 2017). The consumption presented in Table 1 also has not considered the use by industries outside of households. The shortage of milk supply is eventually fulfilled by the supply of imported milk. Until 2016, the supply of imported milk has raised to reach 412,176 tons (Table 1). The growth in milk imports in Indonesia year by year, in general, can lead to huge losses for Indonesia such as a reduction in national foreign exchange and the inability to manage potential resources efficiently and effectively.

Table 1. Development of Import, Availability and Consumption of Milk in 2006-2016 Period

\begin{tabular}{cccc}
\hline Year & Imported Milk (Ton) & $\begin{array}{c}\text { Availability of Local } \\
\text { Milk (Kg/Cap/Year) }\end{array}$ & $\begin{array}{c}\text { Milk Consumption } \\
(\mathrm{Kg} / \text { Cap/Year })\end{array}$ \\
\hline 2006 & 188.128 & 2,34 & 1,48 \\
2007 & 181.520 & 2,12 & 2,25 \\
2008 & 180.933 & 2,39 & 2.13 \\
2009 & 211.634 & 3,01 & 1,95 \\
2010 & 231.396 & 3,16 & 2,07 \\
2011 & 247.495 & 3,35 & 2,11 \\
2012 & 386.116 & 3,30 & 1,69 \\
2013 & 380.558 & 2,67 & 2,07 \\
2014 & 363.531 & 2,68 & 2,20 \\
2015 & 368.844 & 2,76 & 2,58 \\
2016 & 412.176 & 2,97 & 2,67 \\
\hline
\end{tabular}

Source: Ministry of Agriculture, 2017 
This study aimed to analyze the factors affecting the import of dairy milk in Indonesia. The factors studied include exchange rates, GDP per capita, milk exports, and milk production.

\section{RESEARCH METHODS}

This study was conducted in Indonesia using secondary data from 2006-2016 obtained from the Statistics Indonesia and the Ministry of Agriculture as well as supporting literature listed in the bibliography. The dependent variable in this study is the import of milk in Indonesia (Y). The independent variables in this study are the exchange rates (X1), GDP per capita (X2), dairy milk exports $(\mathrm{X} 3)$, and the amount of milk production (X4).

The data analysis technique used was quantitative analysis of multiple linear regression. Before being analyzed, the multiple linear regression model must pass the classical assumption test, including data normality, multicollinearity, heteroscedasticity, and autocorrelation. The multiple linear regression model for this study is shown by equation (Suyana Utama, 2009).

$$
\mathrm{Y}=\alpha+\beta 1 \mathrm{X} 1+\beta 2 \mathrm{X} 2+\beta 3 \mathrm{X} 3+\beta 4 \mathrm{X} 4+\mu 1
$$

Information:

$\mathrm{Y} \quad=$ Impor susu (ton)

$\alpha=$ Constant

$\beta 1 \ldots \beta 3=$ Regression coeficient
$\mathrm{X} 1=$ Exchange rates

X2 = GDP per capita (rupiah)

$\mathrm{X} 3=$ Milk exports (ton)

$\mathrm{X} 4=$ The amount of milk production

$\mu \quad=$ Error

The data analysis technique used in this study was multiple regression equations, in which testings for the accuracy of the model was performed, which were the classical assumption test and statistical test. The classical assumption tests include normality, multicollinearity, heteroscedasticity, and autocorrelation test.

\section{RESULTS AND DISCUSSION}

Data on the import of dairy milk (Y), exchange rates (X1), GDP per capita (X2), dairy milk exports (X3), and the amount of dairy milk production in Indonesia processed in this research are shown in Table 2.

Table 2 shows that the values of the import of dairy milk and GDP per capita continue to increase annually. Unfortunately, this level of imports was not along with the production and export of dairy milk which had fluctuated during 2006-2016. The fluctuating production of dairy milk reflects the high demand for imports of dairy milk to meet the domestic consumption needs of dairy milk. Besides, since the rupiah exchange rate tends to weaken against the dollar, this results in a burden for the country import of dairy milk is continuously carried out.

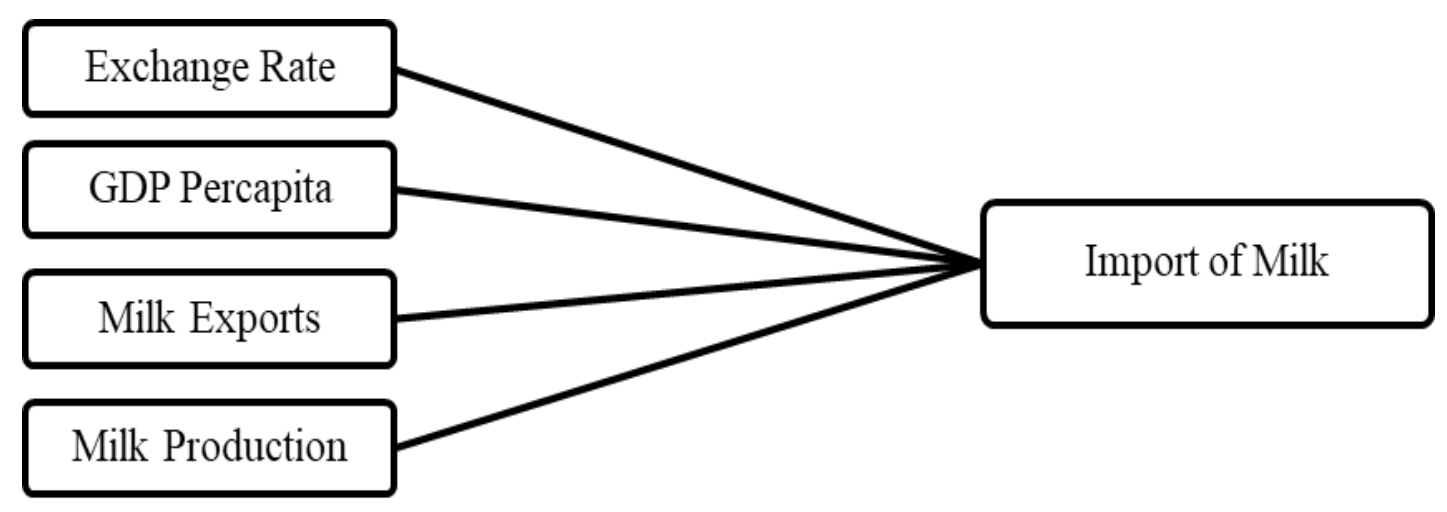

Figure 1. Research Model

Source: Researcher, 2020 
Table 2. Observation Data

\begin{tabular}{cccccc}
\hline Year & $\begin{array}{c}\text { Import of } \\
\text { Milk (Ton) }\end{array}$ & $\begin{array}{c}\text { Exchange } \\
\text { Rates } \\
\text { (Rupiah/USD) }\end{array}$ & $\begin{array}{c}\text { GDP Percapita } \\
\text { (Rupiah) }\end{array}$ & $\begin{array}{c}\text { Milk Exports } \\
\text { (Ton) }\end{array}$ & $\begin{array}{c}\text { Milk } \\
\text { Production } \\
\text { (Ton) }\end{array}$ \\
\hline 2006 & 188.128 & 8.980 & 14.816 .401 & 35.241 & 570.952 \\
2007 & 181.520 & 9.270 & 17.290 .031 & 21.947 & 459.733 \\
2008 & 180.933 & 11.244 & 21.364 .534 & 55.774 & 474.439 \\
2009 & 211.634 & 9.431 & 23.880 .878 & 50.190 & 488.601 \\
2010 & 231.396 & 9.009 & 28.800 .000 & 47.818 & 909.533 \\
2011 & 247.495 & 9.113 & 32.400 .000 & 43.123 & 974.694 \\
2012 & 386.116 & 9.610 & 35.100 .000 & 52.174 & 959.732 \\
2013 & 380.558 & 12.142 & 38.370 .000 & 52.769 & 786.871 \\
2014 & 365.186 & 12.612 & 41.900 .000 & 55.183 & 800.751 \\
2015 & 368.844 & 13.865 & 45.120 .000 & 39.914 & 835.125 \\
2016 & 412.176 & 13.518 & 47.960 .000 & 40.516 & 912.735 \\
\hline
\end{tabular}

Source: BPS and Ministry of Agriculture, 2017

The results of the classical assumption test of the research model show that the research model has met the classical assumption test.

The normality test shows that the residuals were normally distributed based on the Jarque-Bera value of 2.37461 with a $p$ value of 0.305042 where $p>0.05$. The multicollinearity test shows that no multicollinearity issue was found in the research model as the centered VIF value of all variables were less than 10 . The heteroscedasticity test shows that heteroscedasticity indications were not found in the research model as the $p$-value indicated by the value of Prob. chi-square (2) on Obs*R-Squared was 0.4874 and was greater than 0.05 . The autocorrelation test shows that the regression model does not have autocorrelation indications as the p-value indicated by the value of Prob. chi-square (2)

on Obs*R-Squared was 0.9093 , which was greater than 0.05 .

The results of the statistical tests in Table 4 shows that partially, the independent variables of exchange rates, income per capita, exports of dairy milk, and the amount of dairy milk production have a significant effect on the import of dairy milk because they have a probability value of $0.000<0.05$. Meanwhile, the independent variables simultaneously have a significant effect on the import of dairy milk because the significance is $0.000<0.05$.

The results of the statistical test show that $\mathrm{R}^{2}=0.9426$, indicating that the independent variables can explain the dependent variable by $94.26 \%$, and the remaining $5.74 \%$ is affected by other factors.

Based on the results of the statistical test, the equation model of the import of dairy milk in this study is shown by the equation.

Table 3. The Result of Classical Assumption Test

\begin{tabular}{ccc}
\hline Information & Critical Value & Result \\
\hline Normality test & p value $>0,05$ & 0,305042 \\
Multicollinearity test & VIF $<10$ & $<10$ \\
Heteroscedasticity test & Prob. Chi Square $>0,05$ & 0,4874 \\
Autocorrelation test & Prob. Chi Square $>0,05$ & 0,9093 \\
\hline
\end{tabular}

Source: Primary Data Processed, 2019 
Table 4. Results Test for Analysis of Factors that Affecting Milk Imports

\begin{tabular}{ccccc}
\hline Variable & Coeficient & T-statistic & Probability & Information \\
\hline $\mathrm{X} 1$ & -12.38425 & -2.292669 & 0.0358 & Significant \\
$\mathrm{X} 2$ & 0.002703 & 5.998209 & 0.0000 & Significant \\
$\mathrm{X} 3$ & 1.385296 & 2.561361 & 0.0209 & Significant \\
$\mathrm{X} 4$ & 128.8872 & 2.134859 & 0.0486 & Significant \\
$\mathrm{C}$ & -3331.165 & -0.078617 & 0.9383 & - \\
\hline $\mathrm{R}^{2}=0.9426$ & & & & Prob. F $=0.000$ \\
\hline
\end{tabular}

Source: Primary Data Processed, 2019.

$$
\begin{gathered}
\mathrm{Y}=-3331,165-12,38425 \mathrm{X} 1+1,385296 \mathrm{X} 2 \\
+0,002703 \mathrm{X} 3+128,8872 \mathrm{X} 4
\end{gathered}
$$

The variable of the exchange rate has a negative and significant effect on the amount of import of dairy milk. The weakening of the rupiah currency can decrease people's purchasing power so that they will reduce milk consumption. A study by Amaliah and Fahmi (2007) also showed that the real exchange rate of IDR/USD affects the volume of the import of dairy milk significantly in the short and long terms. The import of dairy milk is also affected by the volume of production, the real price of imported milk, and the income per capita. The volume of imported dairy milk is significantly affected by per capita income, and the real exchange rate of IDR/USD, the real price of domestic dairy milk, and the real price of imported dairy milk in the long term.

The variable of GDP per capita has a positive and significant effect on the volume of imported dairy milk. A study by Hastuty Pratiwi (2013) showed that per capita income affects the import of dairy milk in the long run. The real prices of domestic dairy milk and prices of imported dairy milk also affect the import of dairy milk in the long run. Meanwhile, the population aged $>5$ years old, the real price of domestic dairy milk, the real price of imported dairy milk, and the exchange rate affect the import of dairy milk in the short term. National production of dairy milk, exports of dairy milk, the population size of the population aged less than 5 years, and government policies regarding the elimination of imports of dairy milk do not affect imports of dairy milk in the short or long term.

The variable of export of dairy milk has a positive and significant effect on imports of dairy milk. The increase in imports of dairy milk is in line with the increase in exports of dairy milk in Indonesia due to the export of Indonesian milk in the form of raw materials such as milk, cream, and others. Meanwhile, imported dairy milk tends to be in the form of processed milk such as whey, butter, fresh cheese, casein, processed cheese, powdered cheese, buttermilk, yogurt, and others (Ministry of Industry, 2016). The number of exports and imports will change along with changes in the demand and supply of dairy milk. Shadbolt et al. (2016) described that New Zealand as a global trader of dairy products must consider changes in global supply and demand. Asian countries like Indonesia are milk sector-consuming countries with increasing demand for the milk sector at the international level although per capita consumption is still considered to be lower compared to countries in the European Union and North America (Chatellier, 2017). The consumption level of dairy milk in Indonesia is affected by a number of factors such as household expenditure. A study by Ahmad and Hermiyetti (2008) revealed that household expenditure has a positive and significant effect, particularly on the consumption of baby powder milk and sweetened condensed milk.

The variable of milk production has a positive and significant effect on the import of dairy milk. The growth in domestic production of dairy milk remains insufficient for domestic needs so that the import of dairy 
milk is done to meet the domestic needs of dairy milk. Lack of equipment for local dairy farming affects the low efficiency and quality of domestically produced dairy milk (Global Business Guide Indonesia, 2015). Moreover, the drawback in transportation networks such as inadequate road and rail networks and lack of cold storage facilities become logistical challenges for land transportation for the distribution of perishable goods/products such as milk. As a result, the overall demand for dairy products has not been fulfilled although domestic production of fresh milk has increased (Moran \& Morey, 2015). A study by Sharma et al (2005) showed that the high cost of transporting fresh milk for small-scale milk processing businesses in Senegal affects the tendency of businesses to use imported milk powder as a basic material for the manufacture of dairy products.

\section{CONCLUSION}

This study shows that partially, the independent variables of exchange rates, GDP per capita, exports of dairy milk, and milk production have a significant effect on the import of dairy milk because they have a probability value of $0.000<0.05$. The independent variables simultaneously have a significant effect on the amount of the import of dairy milk because the significance is $0.000<0.05$. The coefficient of determination is $94.26 \%$, indicating that the independent variables can explain the dependent variable, and the remaining $5.74 \%$ is affected by other factors. Variables that can increase the import of dairy milk in Indonesia include GDP per capita, exports of dairy milk, and domestic production of dairy milk. Meanwhile, the exchange rate of rupiah can reduce the import of dairy milk.

\section{REFERENCES}

Ahmad, I. and Hermiyetti. 2008. Analisis produksi dan konsumsi susu di Indonesia. Semiloka Nasional Prospek
Industri Sapi Perah Menuju Perdagangan Bebas-2020.

Amaliah, S. and I. Fahmi. 2007. Faktor-faktor yang mempengaruhi impor susu Indonesia. Jurnal Manajemen dan Agribisnis 4(2): 91-102.

Chatellier, V. 2017. International, European and French trade in dairy products: trends and competitive dynamics. Working Paper SMART-LERECO: $1-$ 44. Retrieved from https://ageconsearch.umn.edu/record/2 58070/files/wp17-05.pdf

Direktorat Jenderal Peternakan. 2017. Statistik peternakan 2017. Jakarta: Direktorat Jenderal Peternakan.

Erwidodo, G. Wittwer and R. Stringer. 2009. Effects of agricultural policy reform in Indonesia on its food security and environment from Indonesia. Book Chapter from Reforming world economy: effects on agriculture, trade and the environment: 179-205.

Global Business Guide Indonesia. 2015. Indonesia's dairy industry needs to scale up to meet local demand. http://www.gbgindonesia.com/en/agric ulture/article/2015/indonesia s dairy industry needs to scale up to meet local demand 11207.php. Accessed on January 22, 2020.

Kementerian Perindustrian. 2016. Perkembangan impor kelompok olahan produk susu lainnya. https://kemenperin.go.id/statistik/baran g.php? ekspor $=\&$ kode $=202010043$. Accessed on January 23, 2020.

Moran, J. and P. Morey. 2015. Strategies to Increase the Domestic Production of Raw Milk in Indonesia and other South East Asian Countries. Proceeding of International Seminar on Tropical Animal Production: 1-11.

Pereira, P. C. 2014. Milk nutritional composition and its role in human health. Nutrition 30(6): 619-627. 
Shadbolt, N. M. and D. Apparao. 2016. Factors influencing the dairy trade from New Zealand. International Food and Agribusiness Management Review 19(B): 241-255.

Sharma, R., D. Nyange, G. Duteutre, and N. Morgan. 2005. The impact of import surges: country case study results for Senegal and Tanazia. FAO Commodity and Trade Policy Research Working Paper 11: 1-19.

Song, B., M. A. Marchant, M. R. Reed, and S. $\mathrm{Xu}, 2009$. Competitive analysis and market power of China's soybean import market. International Food and Agribusiness Management Review 12(1): 21-42.

Suaryanti, K. T. 2011. Pengaruh Produksi, Konsumsi, PDB, dan Kurs Dollar AS Terhadap Impor Beras Indonesia Periode 1995-2010. Skripsi. Jurusan Ilmu Ekonomi, Fakultas Ekonomi dan Bisnis, Universitas Udayana.

Yudha. A. E. and S. Hadi. 2009. Analisis pengaruh tingkat suku bunga SBI dan volume ekspor impor terhadap nilai tukar rupiah. Jurnal Ekonomi Pembangunan 7(1): 47-62.

Yuliadi, I. 2008. Analisis impor Indonesia: pendekatan persamaan simultan. Jurnal Ekonomi dan Studi Pembangunan 9(1): 89-104. 